\title{
Lean Technology Implementation For Reducing The Dwelling Time Level
}

\author{
Indra Gunawan ${ }^{1}$, A. Rahim Matondang ${ }^{2}$, Meilita Tryana Sembiring ${ }^{3}$ \\ \{indragunawan2806@gmail.com ${ }^{1}$, meilita_tryana@yahoo.co.id ${ }^{2}$ \} \\ University of Sumatera Utara
}

\begin{abstract}
The high time of port services has resulted in high logistics costs. This is not in accordance with the government's expectations. One way to overcome this can be done through lean technology. Lean focuses on identifying and eliminating non-value added activities in design, production (for manufacturing) or operations (for services) and supply chain management that is directly related to customers.From research on the import service process at BICT port using big picture mapping and process activity mapping, it is known that activities that can be eliminated or reduced are administrative activity and waiting. Non value added and necessary non value added activities decreased from 2370 seconds $(74 \%) \%$ to 878 seconds $(50 \%)$. While the percentage of value added increased from $27 \%$ to $50 \%$. Import dwelling time can be reduced from 72 hours 53 minutes 46 seconds to 24 hours 28 minutes 54 seconds.
\end{abstract}

Keywords: Lean Technology,Dwelling Time, Big Picture Mapping, Process Activity Mapping.

\section{Introduction}

The port is one of the links in the transportation network. The port is also used as a berth area, loading and unloading activities as well as an intra and intermodal transportation mode [Pelindo, 2000]. Belawan International Container Terminal (BICT) is a branch of PT. PELINDO $\mathrm{I}$ is engaged in container and export loading and unloading The problem that often occurs in container terminals in Indonesia is the length of container dwelling time. Dwelling time is the length of time calculated since the goods are unloaded from the ship to the goods out of port [1].According to the Director General of Customs and Excise dwelling Time is the process needed since goods are dropped from ships or goods are piled up until the goods leave the port [2]. Dwelling time is the length of time calculated from the time the goods are unloaded from the ship to the goods out of the port (world bank, 2011).Dwelling time imports in the BICT reached 4.17 days (100.08) hours in 2017. This is still higher compared to ASEAN countries such as Singapore 1 day, Malaysia 1-2 days, Thailand and Vietnam 2-3 days [3].

The company's efforts to increase productivity and reduce the time of loading and unloading services must be done. Companies must know activities that can reduce time or non-value added activities. To achieve this, a lean approach is needed. Lean focuses on identifying and eliminating non value added activities in design, production (for manufacturing) or operations (for services) and supply chain management that is directly related to customers [4].[5] has proven that the application of lean in the service sector has 
increased process flow, reduced waste and increased value added for customers. Lean service is needed to eliminate waste service processes so that costs can be reduced, and better service can be provided as required by customers [6].APICS dictionary (7) defines Lean as a business philosophy based on minimizing the use of resources (including time) in various company activities. Lean focuses on identifying and eliminating non-added value activities in design, production (for manufacturing) or operations (for services), and supply chain management, which is directly related to customers.

[8]defines value added as the difference between a company's sales and purchases of materials and services from other companies. In detail, [9]stated that this activity was aimed at adding net value to the company's output. Another source, [10]defines value added service as a process that provides added value for output and products or services; that is, the activities, benefits, costs and resources they consume.Interpreting value added service (VAS) as a service that contributes to the efficiency of the logistics process and thus increases the value of goods; This service is the source of value added, which consists of wages, depreciation and profits.

The main principle of the lean approach is the reduction or elimination of waste. Waste can also be interpreted as non value added activities for company throughput.

There are seven types of waste (seven wastes) identified by Shigeo Shingo[11], namely:

1. OverProduction.

2. Defect(Reject).

3. UnnecessaryInventory Delay.

4. InappropriateProcessing.

5. ExcessiveTransportation.

6. Waiting/Idle.

7. UnnecessaryMotion.

The fundamental goal of lean service is to minimize waste continuously to maximize the flow of[12]. Based on research, [13] conducted lean research on the export process at the Surabaya container terminal (TPS) and proved there was a reduction in service time.

\section{Methodology}

The research was conducted by identifying the activities of container loading and unloading services. From the service process activities, big picture mapping is done to describe the flow of processes, materials and information.

\section{Results And Discussion}

\subsection{Analysis of Waste}

Waste identification is carried out in the process of loading containers. To get waste information that often occurs in the import service process is done by distributing questionnaires to 10 respondents who understand this problem. Respondents were asked to give an assessment of each waste attribute identified according to the Likert scale. Based on the results of the questionnaire obtained, it can be seen that the sequence of waste most often occurs in the process of container dwell time as shown in Table 1. 
Table 1. Order of Waste Container Loading and Unloading Service Process

\begin{tabular}{lcc}
\hline Seven Wate of Service & Average Weight & Rank \\
& & 2 \\
\hline Over production & 3,6 & 3 \\
Exessive transportation & 3,3 & 6 \\
Unnecessary inventory delay & 2,3 & 5 \\
Innapropiate processing & 2,8 & 1 \\
Waiting & 4,6 & 4 \\
Exess motion & 3,2 & 7 \\
Deffect & 2,2 & \\
\hline
\end{tabular}

\subsection{Big Picture Mapping}

Big Picture Mapping is used to describe the production system / process flow along with the value stream that gives an idea of the flow of information and the physical flow of the existing system, identifying where the waste occurs, and describing the lead time needed based on each process characteristic that occurs.

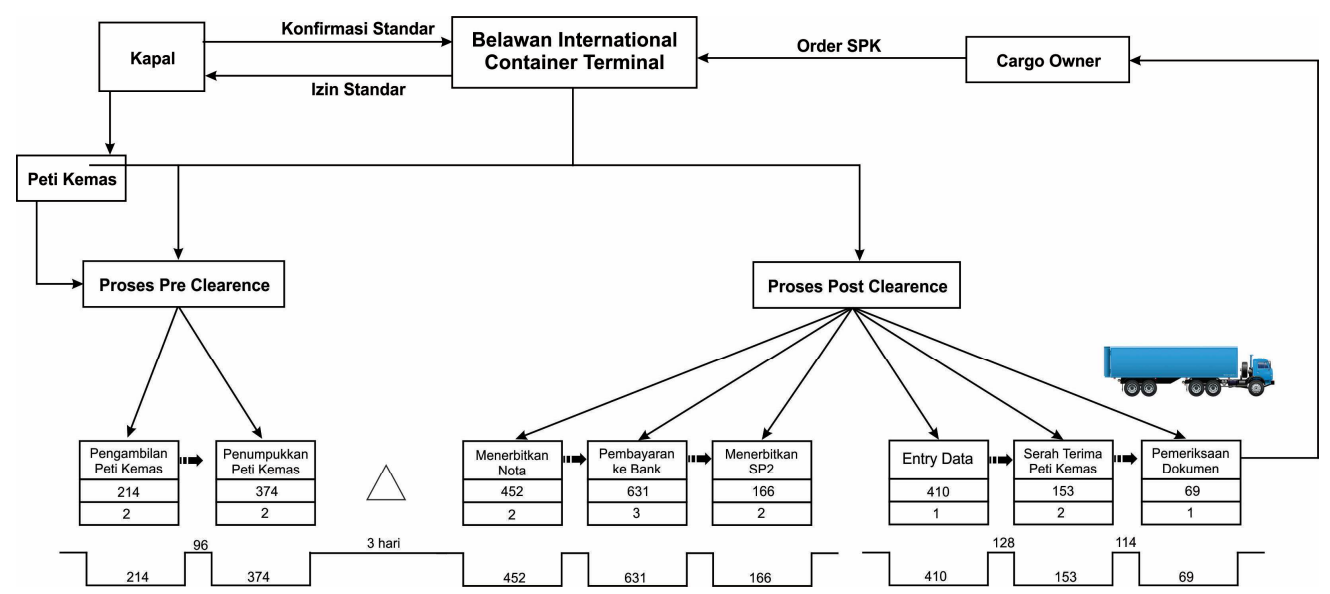

Fig.1. Big Picture Mapping

From the big picture mapping activities can be identified activities that can be reduced namely the activity of waiting in the container yard, issuing notes and payment of notes in the bank.

\section{Conclusions}

By identifying the big picture and using $5 \mathrm{~W} 1 \mathrm{H}$, it is known that waiting activities can be reduced and the issuance of memorandum of payment notes in bank activities can be removed.So that a reduction in time from 72 hours 53 minutes 46 seconds to 24 hours 28 minutes 54 seconds. 


\section{Acknowledgement}

The author would like to thank Belawan International Container Terminal for the research facilities.

\section{References}

[1] Refas, Salim \& Cantens, Thomas (2011), Policy Research Working Paper 5565, World Bank)

[2] Majalah Warta Bea dan Cukai Edisi Mei (2014)

[3] Zaldi (2016), Ini Penyebab Dwelling Time di Indonesia Terlalu Lama di Asean, Tempo.co 2016.

[4] Womack, J. and Jones, D (2003), Lean Thinking, New York: Simon \& Schuster

[5] Radnor at al (2006) Evaluation of The Lean Approach to Bussiness Management And Its Use In The Public Sector, Scottish Executive Social Research.

[6] Qu, L., Ma, M. \& Zhang, G., 2011. Waste analysis of Lean Service. Int., Conf., on Management andService Science, MASS 2011, Wuhan

[7] Blackstone,J.\&Cox,J.,2005,APICSDictionary,APICSTheAssosiationfor Operation Management.

[8] Samuelson, E., Nordhous, N. (1998). Microeconomics, (pp.457-458). New York: Mc Graw-Hill.

[9] Lipsey, G.R. (1983). An introduction to positive economics, (pp. 510-511). London: Harper and Row

[10] Verio, Ltd. (2000). Dictionary of Wisdom system. http://www.wisdomsystem.com.

[11] Hines, Peter, and Taylor, David. (2000), Going Lean. Proceeding of Lean Enterprise Research Centre Cardiff Business School, UK

[12] Seth, D. \& Gupta, V.(2005) "Application of value stream mapping for lean operations and cycle time reduction: an Indian case study", Production Planning \& Control 16, 44-59.

[13] Tumbol, Pierre Rochel (2015), Implementasi Lean Strategy Pada Kegiatan Receiving Di Terminal Petikemas.ITS Surabaya. 
